ROCZNIKI HUMANISTYCZNE

Tom LXVII, zeszyt $10-2019$

DOI: http://dx.doi.org/10.18290/rh.2019.67.10-11

MAŁGORZATA WIDEŁ-IGNASZCZAK

\title{
KOMPONENT LEKSYKALNY \\ W NAUCZANIU ROSYJSKIEJ KOMUNIKACJI BIZNESOWEJ
}

\section{UWAGI WSTĘPNE}

Nauczanie języków obcych specjalistycznych dla celów zawodowych jest połączeniem kompetencji lingwistycznej, fachowej oraz socjokulturowej. Cele i treści nauczania są ukierunkowane na potrzeby uczących się oraz m.in. na rozwój profesjonalnej kompetencji zawodowej, z uwzględnieniem optymalnego funkcjonowania $w$ danej sferze życia ${ }^{1}$ (Europejski system opisu kształcenia językowego: uczenie się, nauczanie, ocenianie, (dalej: ESKJ), 120). Głównym założeniem i nadrzędnym celem konstruowania tak zorientowanych kursów językowych jest efektywność nauczania i uczenia się języków specjalistycznych. Skuteczność wysiłków nauczycieli w tym zakresie umożliwia sprecyzowanie nie tylko językowych, ale także zawodowych i socjokulturowych treści nauczania oraz dobór adekwatnych i różnorodnych środków dydaktycznych ${ }^{2}$.

Zaprezentowana poniżej analiza wprowadzania komponentu leksykalnego w nauczaniu rosyjskiej komunikacji biznesowej jest wynikiem doświadczeń pracy ze studentami w ramach zajęć prowadzonych w Instytucie Filologii Słowiańskiej Katolickiego Uniwersytetu Lubelskiego Jana Pawła II, gdzie od kilku lat realizowana jest specjalizacja „Rosyjski język komunikacji biznesowej”, utworzona w celu zwiększenia szans absolwentów Filologii Słowiańskiej na rynku pracy przy

Dr MaŁgorzata WideŁ-Ignaszczak - adiunkt w Instytucie Filologii Słowiańskiej Katolickiego Uniwersytetu Lubelskiego Jana Pawła II; e-mail: goswid@gmail.com

${ }^{1}$ D. Coste et al., Europejski system opisu ksztatcenia językowego: uczenie sie, nauczanie, ocenianie, przeł. W. Martyniuk, red. nauk. H. Komorowska. Warszawa: Wydawnictwo Centralnego Ośrodka Doskonalenia Nauczycieli 2003.

${ }^{2}$ M. Widet-IGNASZcZaK, Obszary wiedzy specjalistycznej i socjokulturowej w nauczaniu rosyjskiej komunikacji biznesowej, „Roczniki Humanistyczne” 10(2015), s. 164. 
uwzględnieniu przygranicznej specyfiki regionu lubelskiego ${ }^{3}$. Kształt specjalizacji ułatwia podjęcie absolwentom pracy w przedsiębiorstwach, uczestniczących we współpracy i w wymianie gospodarczej z krajami wschodniosłowiańskimi, w sektorze usług biznesowych, obsłudze ruchu turystycznego z Europą wschodnią oraz w służbie celnej na wschodniej granicy Unii Europejskiej. Nieodzowną częścią specjalizacji są także praktyki zawodowe, w ramach których studenci wykorzystują w pracy zawodowej opanowane umiejętności językowe. Program specjalizacji zatem przygotowuje absolwentów do funkcjonowania w środowisku zawodowym. Przy jego projektowaniu przeanalizowano potrzeby uczących się - tj. warunki, miejsca i okoliczności wykorzystania wiedzy i zdobytych umiejętności. Odpowiednio zaplanowane treści nauczania w zakresie nauczania języka specjalistycznego przyczyniają się do podniesienia znajomości języka obcego, nabycia kompetencji społecznych i ułatwienia studentom wejścia na rynek pracy.

O ile kryterium tematyczne samo w sobie jest niewystarczające dla precyzyjnego zdefiniowania języków specjalistycznych, o tyle okazuje się bardzo przydatne w kontekście edukacyjnym i z powodzeniem jest stosowane od lat w dydaktyce. Praktyka dydaktyczna w ciągu minionych lat pokazała, że w różnych tradycjach językowych w różny sposób rozwiązuje się problemy metodyczne dotyczące nauczania języka fachowego (Language for specific purposes - LSP), czego odzwierciedleniem jest wielość określeń funkcjonujących w odniesieniu do języków specjalistycznych w różnych krajach ${ }^{4}$.

${ }^{3}$ Aktualny stan udziału języków specjalistycznych w programach nauczania na kierunkach slawistycznych w Polsce przedstawiła Maria Mocarz-Kleindienst. Szczegółowo zostały zaprezentowane specjalizacje zawodowe, w tym rosyjski język komunikacji biznesowej, wraz z omówieniem przedmiotów kształcenia językowego oraz przedmiotów kształcenia fachowego (M. MocARz-KLEINDIENST, Języki specjalistyczne w programach nauczania na kierunkach slawistycznych, w: Nauczanie języków obcych na potrzeby rynku pracy, red. M. Sowa, M. Mocarz-Kleindienst, U. Czyżewska, Lublin: Wydawnictwo KUL 2015, s. 92-95). Sytuację dotyczącą zmian w sposobie nauczania rosyjskiego języka biznesu w różnych ośrodkach akademickich w Polsce w pierwszym dziesięcioleciu XXI wieku opisała także Nataliya Krenska (N. KRENSKA, Русский язык бизнеса в Польше - его основные проблемы, w: Koтипikacja specjalistyczna, t. II: Specyfika Języków specjalistycznych, red. Stanisław Szadyko, Warszawa: Katedra Języków Specjalistycznych UW 2009, s. 150-153).

${ }^{4} \mathrm{~W}$ zakresie dydaktyki języka rosyjskiego w biznesie najobszerniej zagadnienia te podejmuje Grzegorz Ziętala (Мир русского бизнеса в обучении специилистов по деловому русскому языку, Щецин: Volumina.pl, 2012a; Мир русского бизнеса в практике преподавания. Методические рекомендации и упражнения, Щецин: Volumina.pl, 2012b). Por. M. SowA, Nomenklatura na ustugach glottodydaktyki. Koncepcje nauczania języka francuskiego dla potrzeb zawodowych, „Języki Obce w Szkole” 3(2016), s. 5-7. 
Nieodzownym komponentem każdego aktu komunikacyjnego jest temat, który określa treść komunikatu językowego. Temat może wpływać przede wszystkim na dobór leksyki. Znaczenie leksyki jako komponentu nauczania języka obcego zmienia się w zależności od celów nauczania. W niniejszym artykule omawiana jest sytuacja, gdy podstawowym celem nauki jest umiejętność skutecznego porozumiewania się w sytuacjach zawodowych oraz rozwój profesjonalnej kompetencji komunikacyjnej - słownictwo zatem odgrywa w tym przypadku rolę wiodącą. Mamy do czynienia z taką sytuacją, gdy umiejętność adekwatnego przekazu informacji specjalistycznej jest najmocniej uzależniona od poziomu opanowania słownictwa. Według Hanny Komorowskiej to właśnie braki na poziomie leksyki najbardziej uszkadzają, a nawet blokują przekaz. Blokada komunikacji to zatem najczęściej skutek nieznajomości adekwatnego sytuacyjnie słownictwa ${ }^{5}$.

Magdalena Sowa konstatuje, że nauczanie języków obcych dla potrzeb zawodowych charakteryzuje się niezwykłą różnorodnością i niepowtarzalnością odbiorców, którzy każdorazowo wyrażają odmienne oczekiwania i potrzeby względem potrzebnego im kształcenia językowego. Konsekwencją tego stanu rzeczy jest świadome i przemyślane zawężenie zakresu działań dydaktycznych nauczyciela do tych elementów kształcenia kompetencji komunikacyjnej w języku obcym, które są niezbędne do skutecznego działania w obszarze zawodowym ${ }^{6}$.

\section{CHARAKTERYSTYKA LEKSYKI ROSYJSKIEGO JĘZYKA BIZNESU}

Na podstawie przytoczonych powyżej argumentów należy konstatować, że aby właściwie skonstruować zadania językowe potrzebna jest pogłębiona znajomość specyfiki leksyki danego obszaru językowego - w naszym przypadku: rosyjskiego języka biznesu. Omówienie i uświadomienie sobie tego aspektu w prowadzeniu zajęć z zakresu języka rosyjskiego w biznesie jest fundamentalne z punktu widzenia adekwatnego doboru oraz prezentowania materiału leksykalnego, szczególnie na wyższych poziomach biegłości językowej uczących się - na przykład na studiach filologicznych.

\footnotetext{
${ }^{5}$ H. Komorowska, Ćwiczenia komunikacyjne w nauce języka obcego, Warszawa: Wydawnictwa Szkolne i Pedagogiczne 1988, s. 75; por. A. Seretny, E. LiPIŃSKA, ABC metodyki nauczania języka polskiego jako obcego, Kraków: Wydawnictwo Universitas 2005, s. 75.

${ }^{6}$ M. Sowa, Nomenklatura na ustugach glottodydaktyki, s. 7.
} 
Rzeczywistość językowa współczesnych Rosjan skomplikowała się i uległa wielu zmianom. Przemiany polityczne, społeczne, gospodarcze na przełomie XX i XXI wieku wpłynęły na współczesny język rosyjski. Rozpatrując rosyjski subjęzyk biznesu należy uwzględniać znaczące jego modyfikacje, jakie zaszły w Rosji przede wszystkim w wyniku pieriestrojki. Zmiany w zasobie leksykalnym odzwierciedlają zmieniającą się rzeczywistość. Jak słusznie stwierdza Zofia Czapiga, ogół współczesnych zdarzeń i procesów w dowolnej sytuacji językowo-kulturowej daje się ująć w ramy trzech tendencji: demokratyzacji, marketyzacji i technologizacji. Według uczonej demokratyzacja polega przede wszystkim na aktywnym rozwoju funkcjonalnych odmian języka, marketyzacja odwołuje się do wpływu mechanizmów rynkowych na współczesny język rosyjski, natomiast technologizacja dyskursu jest według niej spowodowana dynamiką otaczającego świata. Zmieniająca się rzeczywistość rodzi potrzebę tworzenia nowego nazewnictwa połączonego z rodzimymi procesami słowotwórczymi, napływem wyrazów obcego pochodzenia oraz często $\mathrm{z}$ neosemantyzacją, tj. procesem nadawania znanym nazwom nowego znaczenia ${ }^{7}$. Procesy te są charakterystyczne dla współczesnego rosyjskiego słownictwa biznesowego.

Grzegorz Ziętala podkreśla, że przejściu od upolitycznionej gospodarki nakazowej do rynkowej towarzyszyła strata tradycyjnych dla radzieckiej gospodarki wartości i norm. Nowe wartości związane z gospodarką wolnorynkową tworzyły nie tylko nowe nazewnictwo, ale nawet nowe stereotypy zachowania i oceny w świadomości masowej, np. usługi w pośrednictwie, wcześniej oceniane jako spekulacja, zostały nazwane nowym słowem посредник. Autor zwrócił także uwagę na odradzające się również stereotypy: kupno-sprzedaż towarów na wolnym rynku, pośrednictwo handlowe, pożyczka. Jednostki leksykalne związane z gospodarką ,centralnie planowaną” obecnie mają status historyzmów: np. план, перевыполнить, передовик, новатор, пятилетка. Terminologia ekonomiczna przed pieriestrojką funkcjonowała w opozycjach swój/obcy, nasze/ich - oddzielne terminy ekonomiczne występowały w starych słownikach, lecz określały zachodnią, burżuazyjną, kapitalistyczną rzeczywistość ${ }^{8}$.

W kontekście przedstawionych powyżej zależności między sytuacją językową i pozajęzykową lingwiści wyróżniają 3 zasadnicze grupy współczesnej rosyjskiej terminologii ekonomicznej:

${ }^{7}$ Z. CZAPIGA, O zmianach w rosyjskim systemie leksykalnym końca XX wieku, w: Rosyjski język biznesu w szkole wyższej. Бизнес-русский в высшей школе, red. A. Paliński, G. Ziętala, Rzeszów: Wydawnictwo Uniwersytetu Rzeszowskiego 2005, s. 39-45.

${ }^{8}$ G. ZIĘTALA, Nauczanie rosyjskiego języka biznesu na studiach rusycystycznych, Rzeszów: Wydawnictwo Uniwersytetu Rzeszowskiego 2004, s. 68. 
1. Stały zasób terminologii ekonomicznej (dotyczący wszystkich typów gospodarki) - są to terminy odzwierciedlające podstawowe pojęcia i kategorie ekonomii jako nauki, np.: производство, потребление, производственные отночения, производительные силы, капитал, спрос, предложение, товар, стоимость, иена, деньги, бюджет, начиональный доход, экспорт, импорт i in.

2. Terminy „powracające” - są to jednostki leksykalne odnoszące się do realiów carskiej Rosji, a które obecnie aktualizują się we współczesnym języku rosyjskim w nowej rzeczywistości gospodarczej, np. акционерное общество, семейное предприятие, паевое товарищество, фирма, биржа, биржевая сделка, биржевой маклер i in.

3. Zapożyczenia z języków obcych, w tym internacjonalizmy: менеджмент, маркетинг, консалтинг, инжиниринг, холдинг, лизинг, трансферт, офшор, аудит, дилер, дистрибьютор, спонсор, чартер, фьючерс, дивиденды, эмиссия, ипотека, ноу-хау, тендер, депозитарий i in. ${ }^{9}$ Konieczność uwzględnienia szerokiego zakresu leksyki z dziedziny terminologii biznesowej wynika z wieloznaczności samego rosyjskiego słowa экономика (gospodarka), traktowanego jako 1. zbiór uwarunkowań gospodarczych danego społeczeństwa - w definicji znajdujemy takie komponenty znaczenia jak: экономика феодализма, капиталистическая экономика, экономика социализма; 2. powiązany system przemysłu, rolnictwa, handlu i usług, istniejący na jakimś terenie: экономика Севера, экономика страны, экономика транспорта, экономика торговли, кризис экономики, теневая экономика; 3. dyscyplina naukowa: экономика управления, учебник по экономике, основы экономики, лекция по экономике производства ${ }^{10}$.

Terminologia sfery biznesu jest niejednorodna - zawiera pojęcia abstrakcyjne i konkretne. G. Ziętala podkreśla również, że najważniejszym elementem w przestrzeni tematycznej jest pojęcie „rynek” jako obiekt wymiany towaroшеј (рынок товаров и услуг, рынок капитала, рынок автомобилей, рынок рабочей силь, рынок иенных бумаг рынок недвижимости) oraz jako obiekt granic wymiany towarowej (мировые рынки, региональные рынки, внутренний и внешний рынок, российский рынок). Pojęсіe rynek dotyczy także stosunków ekonomicznych między uczestnikami wymiany - рынки свободные, замкнутые, регулируемые. Kolejną grupę w przestrzeni nominacyjnej zajmują tzw. predykaty

\footnotetext{
${ }_{9}^{9}$ М.В. КИТАЙГОРОДСКАЯ, Современная эКономическая терминология: (состав, устройство, функиионирование), w: Русский язык конца ХХ столетия (1985-1995), red. Е.А. Земская, Москва: Языки русской культуры 2000, s. 172-175.

${ }^{10}$ Большой толковый словарь русского языка, red. С.А. Кузнецов, Санкт-Петербург: Норинт 2000, s. 1515 (dalej: BTS).
} 
ekonomiczne, które określają podstawowe procesy w sferze ekonomii i stosunków gospodarczych, np. производить (производство), потреблять (потребление), покупать - продавать (купля-продажа), торговать (торговля), арендовать (аренда), кредитовать (кредит, кредитование), инвестировать (инвестиция), страховать (страхование), лицензировать (лицензирование) i in. W komunikacji biznesowej nieodzowne są także jednostki desygnujące nazwy uczestników (stron) relacji ekonomicznych, np. продавец - покупатель, кредитор - должник, заимодавеи - заёмщик, арендатор - арендодатель, страховщик - страхователь, предприниматель, бизнесмен, деловой человек, коммерсант, коммерческий директор, менеджер, аудитор, брокер, маклер, риелтор, агент, a także nazwy typów podmiotów ekonomicznych, np. фирма, картель, синдикат, консорииум, холдинг, финансовые группы, банки, общества. W sferze biznesu ze zrozumiałych względów istotna jest również grupa terminologii dotyczącej pieniędzy, znaków pieniężnych, papierów wartościowych, nр. золотая, серебряная, бумажная валюта, национальная, иностранная, конвертируемая, неконвертируемая, рубль, доллар, фунт, злотый, акция, облигащия, вексель, чек ${ }^{11}$.

Nowe znaczenia wyrazów, intensyfikacja procesu zapożyczeń z języka angielskiego, powrót wyrazów starych do aktywnego zasobu leksykalnego to intensywne procesy odzwierciedlające zmiany leksykalne w sferze komunikacji biznesowej. Charakterystyka niektórych aspektów rosyjskiej leksyki sfery biznesu przedstawiona została ze względu na to, że determinuje dobór materiału językowego dla kursów języka rosyjskiego w komunikacji zawodowej. Zwrócenie uwagi w procesie dydaktycznym na te uwarunkowania, szczególnie na poziomie studiów filologicznych, wydaje się zasadne. Oprócz osiągniecia kompetencji komunikacyjnej w sferze biznesu, opanowania określonego minimum leksykalnego ${ }^{12}$, celem nauczania rosyjskiego języka biznesu na poziomie studiów filologicznych jest także osiągniecie przez studentów kompetencji kulturowej, poprzez właściwe wprowadzanie komponentu leksykalnego (np. objaśnienia, dygresje, symulacje autentycznych sytuacji i in.). Brak wiedzy na temat kultury rosyjskiej, zachowania społecznego (ros. социальное поведение) i istotnych aspektów historii gospodarczej obszaru rosyjskojęzycznego nierzadko tworzy

${ }^{11}$ G. ZiĘTALA, Nauczanie rosyjskiego języka biznesu na studiach rusycystycznych, s. 71-73.

${ }^{12}$ Minima leksykalne do poszczególnych stopni biegłości językowej (poziomu podstawowego, poziomu średniozaawansowanego i zaawansowanego) w zakresie języka rosyjskiego w biznesie opracowane są m.in. dla celów przeprowadzenia egzaminów państwowych organizowanych przez Państwowy Instytut Języka Rosyjskiego im. A.S. Puszkina w Moskwie oraz Izbę Przemysłowo-Handlową Federacji Rosyjskiej (PB, PSZ, PZ). 
bariery dla skutecznej komunikacji. Doniosłość tych czynników podkreślają warszawscy uczeni Łukasz Karpiński i Stanisław Szadyko, pisząc:

Общение с человеком из другой культуры без соответствующего уровня знаний может лишить бизнесмена части детерминантов эффективной коммуникации с представителем именно этой культуры. И поэтому следует особое внимание обратить на взаимные отношения будущих партнеров, учитывая не только стереотипы, но и отличия, а также сходства невербального языка, понимания стилистических и социокультурных особенностей их поведения, а также форм вежливости и др. ${ }^{13}$

\section{ROZWIJANIE KOMPETENCJI LEKSYKALNEJ W ZAKRESIE JĘZYKA ROSYJSKIEGO W BIZNESIE}

Kompetencja leksykalna jest zjawiskiem złożonym i wieloaspektowym. Za Anną Seretny i Ewą Lipińską należy stwierdzić, że „w jej zakres wchodzi zdolność prawidłowej odmiany wyrazów, umiejętność językowego odnalezienia się w określonym kontekście, posługiwanie się frazeologią, odcieniami znaczeniowymi, różnorodnymi stylami”" ${ }^{14}$.

Od uczących się języka rosyjskiego biznesu oczekujemy, że ich kompetencja leksykalna nie będzie jedynie efektem pamięciowego opanowania słownictwa specjalistycznego, rygorystycznej terminologii ekonomicznej, ale polegać będzie także na zdolności do twórczego posługiwania się jednostkami leksykalnymi, do umieszczania ich w kontekstach związanych z komunikacją biznesową, wykorzystywania ich łączliwości z leksyką ogólną, aktualizowania w profesjonalnych kontekstach ich potencjału semantycznego. O takiej sytuacji A. Seretny pisze, że jest to znajomość słownictwa „w głąb” ${ }^{15}$.

Nauczanie słownictwa obejmuje 3 etapy, są to: prezentacja, utrwalenie i powtarzanie nowego materiału. W dydaktyce języków obcych wypracowano już strategie związane z efektywnym nauczaniem słownictwa. A. Seretny i E. Lipińska podkreślają:

${ }^{13}$ Ł. KARPIŃSKI, S. SZADYко, Обучение специальным языкам в польских вузах (на примере русского языка делового общения), „Linguodidactica” 12(2008), s. 80.

${ }^{14}$ A. Seretny, E. LipińsKa, ABC metodyki nauczania języka polskiego jako obcego, s. 76.

${ }^{15}$ A. Seretny, Kompetencja leksykalna uczacych się języka polskiego jako obcego w świetle badań ilościowych, Kraków: Wydawnictwo Uniwersytetu Jagiellońskiego 2011a, s. 49. 
Słownictwa języka obcego nauczamy w sposób pośredni i bezpośredni. [...] Ten ostatni ma miejsce, kiedy uczący się wykonują specjalnie przygotowane ćwiczenia, uczą się słów powiązanych $\mathrm{z}$ tematem, odgadują słowa $\mathrm{z}$ kontekstu, biorą udział w grach słownikowych. Z nauczaniem pośrednim mamy do czynienia, gdy uwaga uczącego skupiona jest na innych zagadnieniach, np. na wiadomości przekazywanej przez mówiącego lub piszącego, na zdobywaniu oraz przekazywaniu informacji ${ }^{16}$.

Rozległe pole leksyki biznesowej w języku rosyjskim tworzą przede wszystkim zwroty, wyrażenia idiomatyczne i kolokacje, ale także pojedyncze wyrazy (głównie rzeczowniki). Leksykalny wymiar języka biznesu nie jest zatem zbiorem izolowanych wyrazów, lecz siecią różnorodnych powiązań składniowo-semantycznych łączących poszczególne słowa. Ta sieć stanowi podstawę, na której wspiera się językowa komunikacja biznesowa. Warto więc dołożyć starań, by w procesie dydaktycznym pogłębianie kompetencji leksykalnej wiązało się nie tylko z przyswajaniem słownictwa, lecz także z sukcesywnym poszerzaniem wiedzy o złożonych relacjach między słowami, o ich potencjale semantycznym i o ładunku kulturowo-społecznym, którego nośnikiem jest każda jednostka terminologii związanej z gospodarką wolnorynkową w Rosji.

W odniesieniu do rozpatrywanego komponentu leksykalnego nauczania rosyjskiej komunikacji biznesowej przyjmuję następującą tezę Hanny Komorowskiej:

[...] skoro słownictwo okazuje się elementem najsilniej warunkującym komunikatywność wypowiedzi, to nie tylko może, ale i powinno być przedmiotem specjalnych ćwiczeń leksykalnych, jego opanowanie nie powinno być tylko efektem ubocznym rozwoju sprawności językowych. Powtarzanie i utrwalanie słownictwa w toku ćwiczeń w mówieniu, słuchaniu, pisaniu lub czytaniu to działalność wartościowa, ale tylko pod warunkiem, że w nauczaniu występują stałe konsekwentnie prowadzone ćwiczenia ściśle leksykalne ${ }^{17}$.

Szczegółowo omówione zostaną charakterystyczne techniki nauczania leksyki biznesowej w ramach kursu „Rosyjska terminologia ekonomiczna”, realizowanego w ramach wspomnianej wcześniej specjalizacji „Język rosyjski komunikacji biznesowej”. Przy przygotowaniu zestawu technik i ćwiczeń leksykalnych

${ }^{16}$ A. Seretny, E. LipińsKa, ABC metodyki nauczania języka polskiego jako obcego, s. 86.

${ }^{17}$ H. KomorowsKa, Ćwiczenia komunikacyjne w nauce języka obcego, s. 76; por. A. SERETNY, Stownictwo a programy nauczania - komponent leksykalny ksztatcenia językowego, w: W poszukiwaniu nowych rozwiazań. Dydaktyka języka polskiego jako obcego u progu XXI wieku, red. Władysław Miodunka, Anna Seretny, Kraków: Wydawnictwo Uniwersytetu Jagiellońskiego 2008, s. 135. 
wykorzystano teoretyczne opracowania A. Seretny i E. Lipińskiej ${ }^{18}$, H. Komorowskiej ${ }^{19}$ oraz G. Ziętali ${ }^{20}$. W niniejszym artykule ze względu na ograniczenia redakcyjne omówione zostaną tylko najczęstsze ćwiczenia leksykalne o charakterze przedkomunikacyjnym.

\subsection{NAJCZESTSZE TECHNIKI WPROWADZANIA NOWEJ LEKSYKI EKONOMICZNEJ}

1) Semantyzacja terminów w języku obcym - definicja w języku rosyjskim, której często towarzyszy komentarz językoznawczy i kulturoznawczy dotyczący samej terminologii. Podkreślić należy, że na poziomie studiów filologicznych terminologia ekonomiczna może być traktowana jako interpretacja rosyjskojęzycznego świata ${ }^{21}$, np.:

Существует ряд основных видов бирж, специализирующихся на конкретных торгуемых инструментах:

а) Товарная биржа - централизованный рынок товаров. На современных биржах продается в основном стандартизированный товар, скорее даже не сам товар, а лишь контракты на его поставку. Занимается оптовой торговлей массовых товаров. В свою очередь она делится на: Универсальные биржи - здесь идет купля-продажа различных типов продукта и Специализированные биржи - купля-продажа конкретного типа продукта, например, только металлов. Сделки на биржах бывают трех видов: а) с оплатой наличными, в этом случае предполагается немедленная поставка товара; б) срочные, при которых товар должен быть поставлен по истечении определенного срока, указанного в договоре; в) регулируемые, или так называемые сделки на особых биржевых условиях.

б) Валютная биржа - учреждение, в котором осуществляются сделки куплипродажи иностранной валюты, формируются курсы валют (валютные котировки) на основе фактического соотношения спроса и предложения.

в) Фондовая биржа - организованный и регулярно функционирующий рынок по купле-продаже ценных бумаг: акций, облигаций и т. д. Фондовая биржа мобилизует и перераспределяет временно свободные денежные средства между компаниями,

${ }^{18}$ A. SERETnY, E. LipińSKA, ABC metodyki nauczania języka polskiego jako obcego, s. 86-100.

${ }^{19}$ H. Komorowska, Metodyka nauczania języków obcych, Warszawa: Fraszka Edukacyjna 2001, s. 116-123.

${ }^{20}$ G. ZiĘTALA, Nauczanie rosyjskiego języka biznesu na studiach rusycystycznych, s. 138-141.

${ }^{21}$ Por. R. ToKARSKI, Stownictwo jako interpretacja świata, w: Współczesny język polski, red. J. Bartmiński, Lublin: Wydawnictwo UMCS 2001, s. 343. 
отраслями хозяйства и другими сферами приложения, устанавливает рыночную стоимость ценных бумаг.

г) Биржа труда - организация, посредник между работодателями и наемными работниками, занимающаяся трудоустройством. В Российской Федерации это так называемые центры занятости.

д) Фьючерсная биржа - современная форма товарной биржи, торговля на которой ведется фьючерсными контрактами. Торговлю на фьючерсной бирже по сравнению с торговлей реальными товаром на товарной бирже отличают: преимущественно фиктивный характер сделок (лишь 1-2 \% сделок завершаются поставкой товара, а остальные - выплатой разницы в ценах); косвенная связь с рынком реального товара через хеджирование; полная унификация всех условий контракта, кроме цены; обезличенность сделок, так как между покупателем и продавцом стоит расчетная палата.

е) Хеджирование - страхование валютных и других рисков путем внешнеторговых и кредитных операций, изменения валюты торговой или кредитной сделки, создания резервов для покрытия возможных убытков.

2) Synonim i antonim - objaśnienie znaczenia nowego wyrazu przez podanie innego wyrazu, którego znaczenie studenci rozumieją. Są to techniki skuteczne ze względu na wysoki stopień biegłości językowej uczących się oraz bliskie pokrewieństwo języka rodzimego i obcego.

a) Synonimy, np.:

бартер - обмен, бюджет - казна, деловой - предпринимательский, дилер

- торговец, поддержка - финансирование, фискальный - налоговой, сделка

- операция, расходы - затраты, контракт - договор - соглашение, тратта

- переводной вексель, риэлтер -риэлтор.

b) Antonimy, np.:

национализация - приватизация, стабилизация - инфляциия, кризис, фирменный - фальшивый, поддельный, экспорт - импорт.

Technika ta zasługuje na uwagę, gdyż zjawisko występowanie dubletów i ekwiwalentów terminologicznych jest charakterystyczną cechą rosyjskiej terminologii ekonomicznej okresu po pieriestrojce.

3) Polski odpowiednik - dość częsta technika semantyzacji nowej leksyki stosowana w celu osiągnięcia precyzji terminologicznej oraz przygotowania studentów do ćwiczeń translacyjnych (na drugim stopniu kształcenia akademickiego, na studiach magisterskich, wielu studentów podejmuje specjalizację tłumaczeniową), np.: 
жалоба - zażalenie, навалом - luzem, налогообложение - opodatkowanie, ходатайство - wniosek, недвижимость - nieruchomość, валовой внутренний продукт (ВВП) - produkt krajowy brutto (PKB), доверенность - upoważnienie, pełnomocnictwo.

\subsection{NAJCZESTSZE TECHNIKI POWTARZANIA I UTRWALANIA LEKSYKI EKONOMICZNEJ}

Najczęstsze techniki powtarzania i utrwalania leksyki ekonomicznej to:

1) Dopasowywanie definicji do wyrazów - wnioskowanie o znaczeniu słów na podstawie kontekstu lub polsko-rosyjskiej zbieżności fonetycznej, np.:

\section{I. Соедините термин с его определением:}

\begin{tabular}{|l|l|}
\hline $\begin{array}{l}\text { 1) Право на продажу или покупку биржевого товара, валюты или } \\
\text { ценных бумаг (securities) в фиксированном объеме к определенной } \\
\text { дате по цене использования опциона. }\end{array}$ & а) акция \\
\hline $\begin{array}{l}\text { 2) От англ. hedge страховка, гарантия. Страхование валютных } \\
\text { и других рисков путем внешнеторговых и кредитных операций, } \\
\text { изменения валюты торговой или кредитной сделки, создания } \\
\text { резервов для покрытия возможных убытков. }\end{array}$ & б) опцион \\
\hline $\begin{array}{l}\text { 3) Торговля, направленная на заработок средств от того, как будет } \\
\text { изеняться рыночная цена. }\end{array}$ & в) хеджирование \\
\hline $\begin{array}{l}\text { 4) Ценная бумага, являющаяся титулом собственности на часть } \\
\text { имущества компании. }\end{array}$ & г) фьючерсная сделка \\
\hline $\begin{array}{l}\text { 5) Условия этого вида сделок предполагают передачу акции или } \\
\text { товара с уплатой денежной суммы через определенный срок после } \\
\text { заключения сделки по цене, указанной в контракте. }\end{array}$ & д) спекуляция \\
\hline
\end{tabular}

II. Соедините термин с его определением:

\begin{tabular}{|l|l|}
\hline 1) заемщик & $\begin{array}{l}\text { а) сумма, принимаемая банком под определенный процент на } \\
\text { условиях, определенных договором }\end{array}$ \\
\hline 2) вклад & б) получатель займа \\
\hline 3) ссуда & $\begin{array}{l}\text { в) предоставление денежных средств или имущества на заранее } \\
\text { оговоренный срок }\end{array}$ \\
\hline 4) банкир & г) тот, кому организация или частное лицо задолжали деньги \\
\hline 5) кредитор & д) лицо, гарантирующее выплату долга, взятого кем-то другим \\
\hline 6) гарант & $\begin{array}{l}\text { е) физическое лицо, занимающееся финансовыми операциями в } \\
\text { качестве менеджера или владельца банка }\end{array}$ \\
\hline
\end{tabular}


2) Tworzenie lub świadoma analiza pól semantycznych z uwzględnieniem relacji między komponentami poszczególnych pól. Grupowanie wyrazów według określonego kryterium nie tylko semantycznego, ale również sytuacyjnego, np.: pola semantyczne фирма, налоги, страхование, переговоры itp.

3) Poszukiwanie synonimów lub antonimów do podanych wyrazów lub fraz, np. na podstawie skrupulatnie wyselekcjonowanych fragmentów tekstów ekonomicznych.

4) Techniki wykorzystujące słowniki jednojęzyczne, dwujęzyczne i leksykony specjalistyczne, jak również Narodowy Korpus Języka Rosyjskiego, w szczególności przydatny jest dla tych celów Korpus Gazetowy, np. analiza komponentów definicji słownikowej w ramach jednej kategorii semantycznej w języku rodzimym i języku obcym.

5) Techniki zapewniające dyferencjację leksemów bliskoznacznych - praca ze słownikiem objaśniającym, np.:

I. К данным определениям присоедините правильные варианты видов платежей:

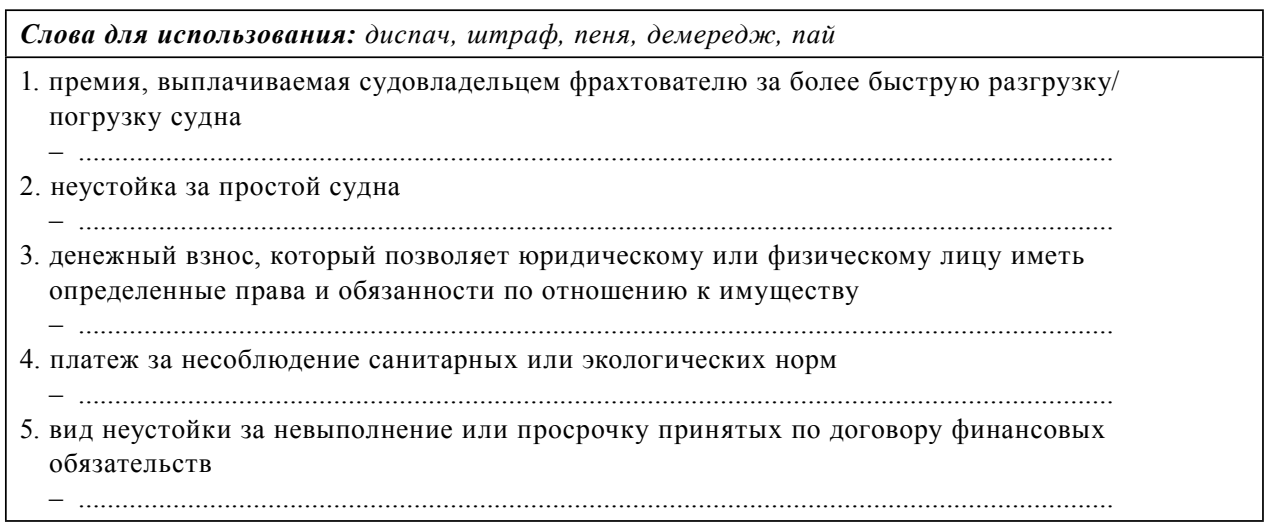

6) Tworzenie związków wyrazowych, zamiana pojedynczych słów kolokacjami. Zasadniczą trudność sprawia studentom opanowanie reguł łączliwości - syntagm konwencjonalnych, które wprawdzie nie utrudniają recepcji i rozumienia komunikatu, ale produkcję językową ${ }^{22}$, dlatego ten typ ćwiczeń jest niezwykle pożądany. Jak słusznie zauważa A. Seretny, „operowanie w procesie kształcenia pojedynczymi słowami sprawia, że uczący się w sposób mniej naturalny posługują

${ }^{22}$ O. MaŁYsa, I. OKSANA, Nauczanie rosyjskiego języka biznesu w szkole wyższej, w: Współczesne problemy dydaktyki języka rosyjskiego na różnych poziomach nauczania, red. Maja Szymoniuk, Katowice: Wydawnictwo Uniwersytetu Śląskiego 1995, s. 57. 
się słownictwem" ${ }^{23}$. Dotyczy to, jak się wydaje, nie tylko szerszych kontekstów komunikacyjnych, ale także tych najmniejszych, tj. poziomu kolokacji. Nauka języka obcego jest traktowana także jako przyswojenie różnic strukturalnych między językiem wyjściowym i językiem docelowym ${ }^{24}$. Za przykład mogą posłużyć następujące zadania:

I. Образуйте все возможные словосочетания из слов левой и правой колонок:

\begin{tabular}{|l|l|l|}
\hline 1. & нести & проценты \\
\hline 2. & финансовый & кредит \\
\hline 3. & оформить & депозит \\
\hline 4. & банковский & ссуду \\
\hline 5. & начислять & ответственность \\
\hline 6. & платежные & переводы \\
\hline 7. & выпускать & средства \\
\hline 8. & безналичные & контроль \\
\hline 9. & открыть & акции \\
\hline 10. & предоставить & счет \\
\hline
\end{tabular}

II. Добавьте определения к следующим существительным:

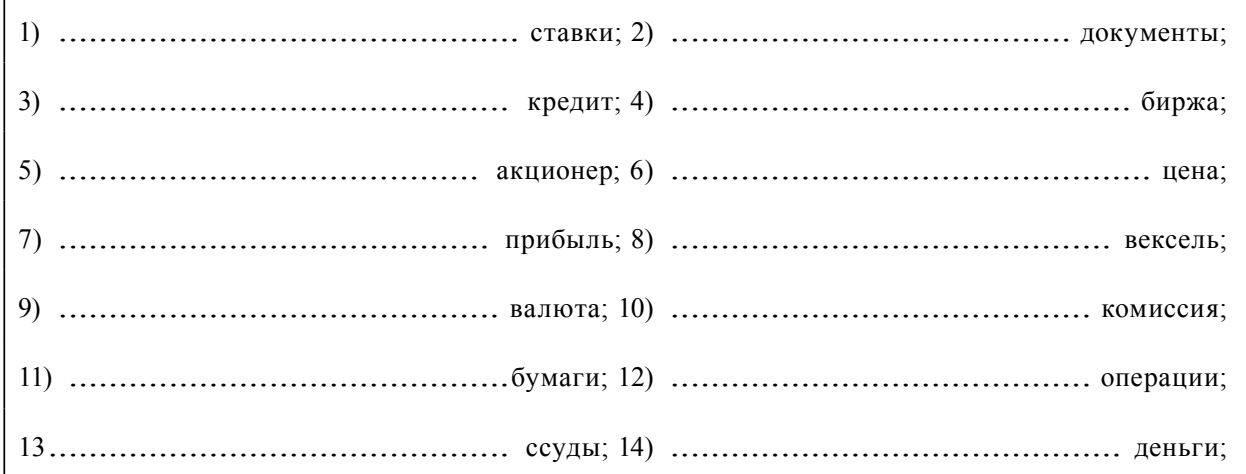

7) Opracowywanie rozbudowanych siatek składniowo-semantycznych. Poniższe 2 przykłady ilustrują efekt zastosowania techniki powtarzania i utrwalania leksyki ekonomicznej:

${ }^{23}$ A. Seretny, Kompetencja leksykalna uczacych się języka polskiego, s. 114.

${ }^{24}$ J. KorzeniewsKa-Rogalewicz, Błąd leksykalny a dydaktyka języka obcego: na materiale języka rosyjskiego, Warszawa: Wydawnictwo Uniwersytetu Warszawskiego 1986, 26-27. 
I. Конструкции, называющие направление деятельности фирмы:

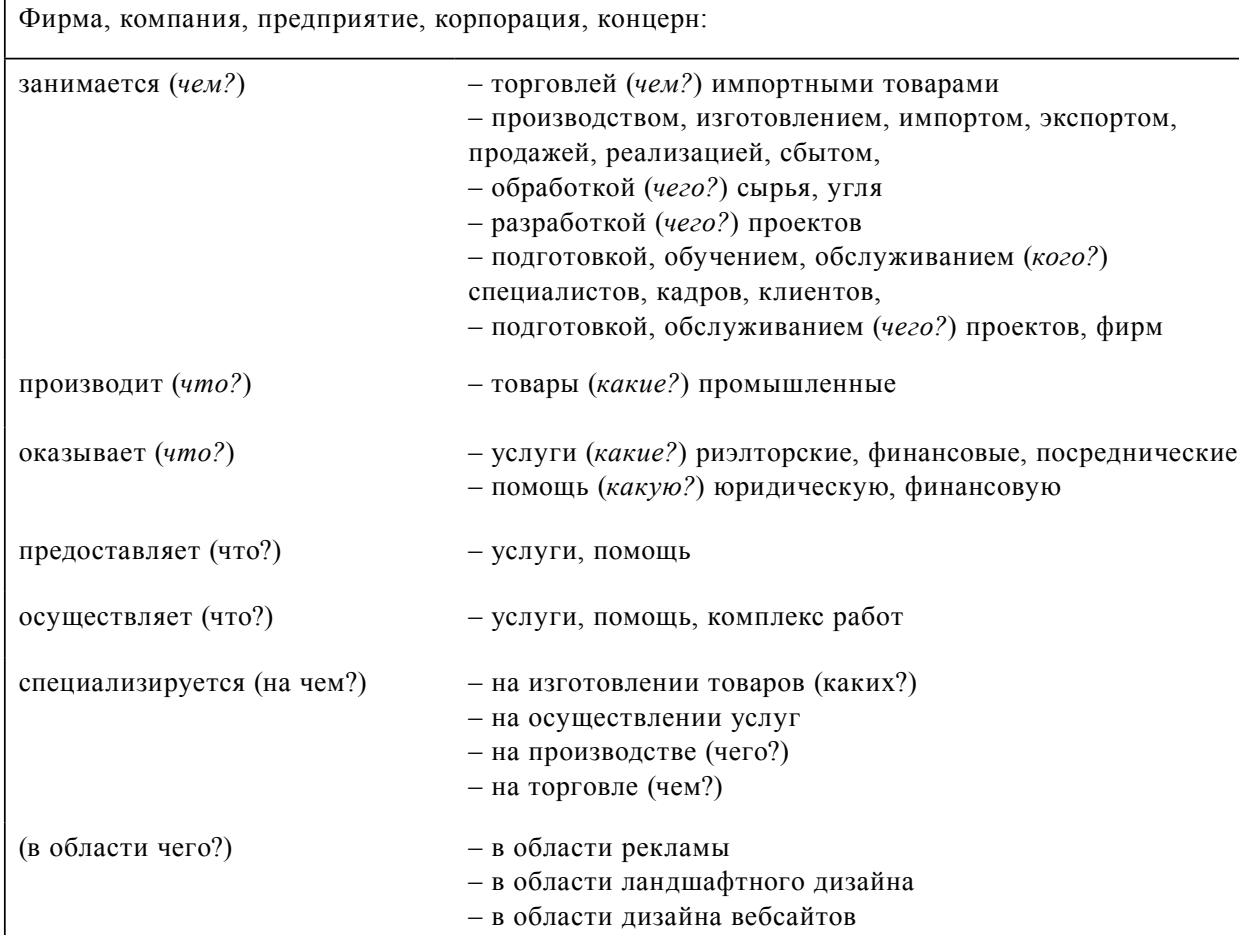

II. Конструкции, описывающие финансовую деятельность фирмы:

актив - любая собственность, которая имеет ценность при обмене

акция - ценная бумага, являющаяся титулом собственности на часть имущества компании (какая?) доходная, именная, обыкновенная, привилегированная, на предъявителя, без указания номинальной цены

(что делать?) выпускать, покупать, продавать, размещать, вкладывать капитал в акции банк (какой?) Акционерный банк - АБ, Акционерный коммерческий банк - АКБ, Банк международных расчетов - БМР,

Внешнеэкономический банк - ВЭБ (Внешэкономбанк), Всемирный банк - ВБ, Европейский банк реконструкции и развития - ЕБРР, Коммерческий банк - КБ, Международный банк реконструкции и развития - МБРР, Национальный банк - НБ

(какой?) банковский кредит, перевод, процент, счет

(какая?) банковская прибыль, ссуда

(какие?) банковские реквизиты

биржа (какая?) бартерная, валютная, международная, товарная, торговая, фондовая, фьючерсная (какой?) биржевой курс, маклер, (какая?) котировка (какая?) биржевая спекуляция, торговля (какие?) биржевые товары, торги 


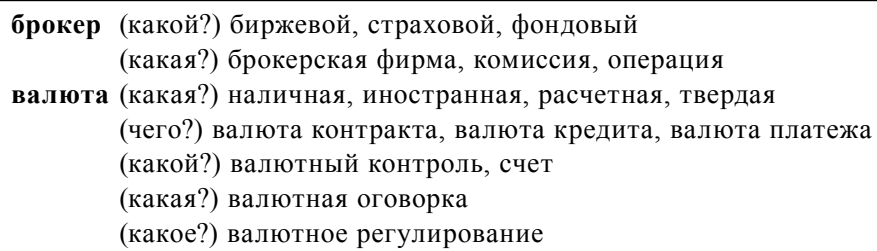

прибыль (какая?) банковская, биржевая, общая, торговая, чистая, от экспорта (что делать?) получать прибыль, терять , приносить , распределять

расчет (какой?) вексельный, безналичный, взаимный, окончательный (что делать?) производить расчеты, осуществлять расчеты

ссуда (какая?) банковская, биржевая, ипотечная, коммерческая, под залог груза, под недвижимость

(что делать?) дать ссуду, предоставить ссуду, получить ссуду, погасить ссуду, возвратить ссуду

счет (какой?) банковский, валютный, коммерческий, кредитный, текущий, (что сделать?) выписать счет, выставить счет, предоставить счет, оплатить счет, открыть счет, закрыть счет, подтвердить счет.

Podczas konstruowania siatek składniowo-semantycznych studenci mają możliwość powtórzenia nie tylko znaczenia słów, ale także dzięki takiemu 
układowi materiału leksykalnego, uczący się dysponują gotowymi konstrukcjami składniowymi, które wykorzystują następnie w ćwiczeniach komunikacyjnych.

Reasumując, należy podkreślić, że praca nad kompetencją leksykalną w zakresie rosyjskiego języka sfery biznesu w układzie glottodydaktycznym obejmuje wprowadzanie słownictwa ekonomicznego oraz powtarzanie i utrwalanie go z uwzględnieniem uwarunkowań pozajęzykowych funkcjonowania w Rosji tej warstwy leksyki. Dbałość o adekwatne uwzględnienie komponentu leksykalnego w ramach omawianego kursu sprawia, że praca odbywa się zarówno w ramach opisanych w tym artykule ćwiczeń przedkomunikacyjnych, jak również ćwiczeń stricte komunikacyjnych. Podobnie jak w procesie komunikacji zawodowej, tak i w nauczaniu języka specjalistycznego, sytuacje, role i używany język powinny być autentyczne ${ }^{25}$. W związku z tym, już na kolejnym etapie ćwiczeń komunikacyjnych preferuje się te techniki, które symulują interakcje, dialogi, debaty, odgrywanie ról, gry i zabawy. Studenci odgrywają konkretne role, np. uczestników sfery biznesu czy pracowników urzędu celnego. Sytuacje są nie tylko zakreślone, ale podawany jest do nich szczegółowy scenariusz, skierowany na utrwalenie i wprowadzenie do aktywnego zasobu słownikowego studenta pożądanej leksyki. To zagadnienie wymaga jednak oddzielnego omówienia z uwzględnieniem aktywizacji poznanej leksyki w ramach wszystkich sprawności językowych - czytania, rozumienia tekstu, mówienia i pisania.

\section{BIBLIOGRAFIA}

BTS - Большой толковый словарь русского языка, red. С.А. Кузнецов, Санкт-Петербург: Норинт 2000 [BTS - Bol'shoy tolkovyy slovar' russkogo yazyka, red. S.A. Kuznetsov, Sankt-Peterburg: Norint 2000].

Cholewa J., Nauczanie języków specjalistycznych wczoraj i dziś, „Języki Obce w Szkole” 4(2013), s. 75-80.

Czapiga Z., O zmianach w rosyjskim systemie leksykalnym końca XX wieku, w: Rosyjski język biznesu w szkole wyższej. Бизнес-русский в высшей школе, red. A. Paliński, G. Ziętala, Rzeszów: Wydawnictwo Uniwersytetu Rzeszowskiego 2005, s. 39-45.

ESKJ - Europejski system opisu kształcenia językowego: uczenie się, nauczanie, ocenianie, przeł. W. Martyniuk, red. nauk. H. Komorowska. Warszawa: Wydawnictwo Centralnego Ośrodka Doskonalenia Nauczycieli 2003.

KARPIŃSKi Ł., SZAdYкo S., Обучение спечиальным языкам в польских вузах (на примере русского языка делового общения), „Linguodidactica” 12(2008), s. 75-80 [Karpiński Ł., Szadyko S., Обучение специальным языкам в польских вузах (на примере русского языка делового общения), „Linguodidactica” 12(2008), s. 75-80].

КитАЙГородсКАЯ М.В., Современная экономическая терминология: (состав, устройство, функционирование), w: Русский язык кониа ХХ столетия (1985-1995), red. Е.А. Земская, Москва: Языки русской культуры 2000, s. 162-236 [Kitaygorodskaya M.V., Sovremennaya ekonomicheskaya terminologiya: (sostav, ustroystvo, funktsionirovaniye), w: Russkiy yazyk kontsa XX stoletiya (1985-1995), red. Ye.A. Zemskaya, Moskva: Yazyki russkoy kul'tury 2000, s. 162-236].

${ }^{25}$ J. CHOLEWA, Nauczanie języków specjalistycznych wczoraj i dziś, „Języki Obce w Szkole” 4(2013), s. 78. 
KomorowsKa H., Ćwiczenia komunikacyjne w nauce języka obcego, Warszawa: Wydawnictwa Szkolne i Pedagogiczne 1988.

KomorowsKa H., Metodyka nauczania języków obcych, Warszawa: Fraszka Edukacyjna 2001.

KorZENIEWSKa-Rogalewicz J., Błąd leksykalny a dydaktyka języka obcego: na materiale języka rosyjskiego, Warszawa: Wydawnictwo Uniwersytetu Warszawskiego 1986.

Krenska N., Русский язык бизнеса в Польше - его основные проблемы, w: Koтипikacja specjalistyczna, t. II: Specyfika Języków specjalistycznych, red. S. Szadyko, Warszawa: Katedra Języków Specjalistycznych UW 2009, s. 146-150 [Krenska N., Russkiy yazyk biznesa v Pol'she - yego osnovnyye problemy, w: Komunikacja specjalistyczna, t. II: Specyfika języków specjalistycznych, red. S. Szadyko, Warszawa: Katedra Języków Specjalistycznych UW 2009, s. 146-150].

MaŁysa O., Murska I., Nauczanie rosyjskiego języka biznesu w szkole wyższej, w: Wspótczesne problemy dydaktyki języka rosyjskiego na różnych poziomach nauczania, red. M. Szymoniuk, Katowice: Wydawnictwo Uniwersytetu Śląskiego 1995, s. 55-61.

Mocarz-KLeIndienst M., Języki specjalistyczne w programach nauczania na kierunkach slawistycznych, w: Nauczanie języków obcych na potrzeby rynku pracy, red. M. Sowa, M. Mocarz-Kleindienst, U. Czyżewska, Lublin: Wydawnictwo KUL 2015, s. 90-97.

PB - ЖуравЛЕва Л.С. et al., Русский язык делового общения. Бизнес. Коммериия, Лингводидактическое описание целей и содержания обучения. Базовый сертификационный уровень, Москва: Государственный Институт им. А.С. Пушкина, 2003 [PB - Zhuravleva L.S. et al., Russkiy yazyk delovogo obshcheniya. Biznes. Kommertsiya, Lingvodidakticheskoye opisaniye tseley i soderzhaniya obucheniya. Bazovyy sertifikatsionnyy uroven', Moskva: Gosudarstvennyy Institut im. A.S. Pushkina, 2003].

PSZ - Журавлева Л.С. et al., Русский язык делового общения. Бизнес. Коммериия, Лингводидактическое описание иелей и содержания обучения. Средний сертификационный уровень, Москва: Государственный Институт им. А.С. Пушкина, 2002 [PSZ - Zhuravleva L.S. et al., Russkiy yazyk delovogo obshcheniya. Biznes. Kommertsiya, Lingvodidakticheskoye opisaniye tseley i soderzhaniya obucheniya.Sredniy sertifikatsionnyy uroven, Moskva: Gosudarstvennyy Institut im. A.S. Pushkina, 2002].

PZ - ЖуравЛева Л.С. et al., Русский язык делового общения. Бизнес. Коммериия. Внешнеторговая деятельность, Лингводидактическое описание иелей и содержания обучения. Продвинутый сертификационный уровень, Москва: Государственный Институт им. А.С. Пушкина 2007 [PZ - Zhuravleva L.S. et al., Russkiy yazyk delovogo obshcheniya. Biznes. Kommertsiya. Vneshnetorgovaya deyatel'nost', Lingvodidakticheskoye opisaniyetseley i soderzhaniya obucheniya. Prodvinutyy sertifikatsionnyy uroven', Moskva: Gosudarstvennyy Institutim. A.S. Pushkina 2007].

SERETNY A., Stownictwo a programy nauczania - komponent leksykalny kształcenia językowego, w: W poszukiwaniu nowych rozwiazań. Dydaktyka języka polskiego jako obcego u progu XXI wieku, red. W. Miodunka, A. Seretny, Kraków: Wydawnictwo Uniwersytetu Jagiellońskiego 2008, s. 131-142.

SERETNY A., Kompetencja leksykalna uczacych się języka polskiego jako obcego w świetle badań ilościowych, Kraków: Wydawnictwo Uniwersytetu Jagiellońskiego 2011a.

SERETNY A., Nauczanie języka specjalistycznego - kolejne wyzwanie glottodydaktyki polonistycznej, w: O nauczaniu i uczeniu się języka obcego dla potrzeb zawodowych, red. S. Piotrowski, Lublin: Wydawnictwo KUL 2011b, s. 106-121. [nie wykorzystane w art.]

Seretny A., Lipińska, E., ABC metodyki nauczania języka polskiego jako obcego, Kraków: Wydawnictwo Universitas 2005.

Sowa M., Nomenklatura na ustugach glottodydaktyki. Koncepcje nauczania języka francuskiego dla potrzeb zawodowych, „Języki Obce w Szkole” 3(2016), s. 4-11.

TOKARSKI R., Stownictwo jako interpretacja świata, w: Wspótczesny język polski, red. J. Bartmiński, Lublin: Wydawnictwo UMCS 2001, s. 343-370.

WideŁ-IgnaszczaK M., Obszary wiedzy specjalistycznej i socjokulturowej w nauczaniu rosyjskiej komunikacji biznesowej, „Roczniki Humanistyczne” 10(2015), s. 163-172.

Zį̨TALa G., Nauczanie rosyjskiego języka biznesu na studiach rusycystycznych, Rzeszów: Wydawnictwo Uniwersytetu Rzeszowskiego, 2004. 
ЗентАля Г., Мир русского бизнеса в обучении спеииалистов по деловому русскому языку, Щецин: Volumina.pl 2012a [Zentalya G., Mir russkogo biznesa v obuchenii spetsialistov po delovomu russkomu yazyku, Szczecin: Volumina.pl 2012a].

ЗЕнтАля Г., Мир русского бизнеса в практике преподавания. Методические рекомендации и упражнения, Щецин: Volumina.pl 2012b [Zentalya G., Mir russkogo biznesa v praktike prepodavaniya. Metodicheskiye rekomendatsii i uprazhneniya, Szczecin: Volumina.pl 2012b].

\section{KOMPONENT LEKSYKALNY W NAUCZANIU ROSYJSKIEJ KOMUNIKACJI BIZNESOWEJ}

\section{Streszczenie}

W artykule podjęto zagadnienie znaczenia komponentu leksykalnego w nauczaniu rosyjskiej komunikacji biznesowej. Podkreślono, że nieodzownym elementem aktu komunikacji biznesowej jest temat, który określa treść komunikatu językowego i wpływa przede wszystkim na dobór leksyki. Znaczenie leksyki jako komponentu nauczania języka obcego zmienia się w zależności od celów nauczania. W niniejszym artykule omawiana jest sytuacja, gdzie podstawowym celem nauki jest umiejętność skutecznego porozumiewania się, rozwój zawodowej kompetencji komunikacyjnej, w której znajomość słownictwa odgrywa wiodącą rolę. Udowodniono, że umiejętność przekazu informacji specjalistycznej jest najmocniej uzależniona od poziomu opanowania słownictwa. Braki na poziomie leksyki najbardziej uszkadzają, a nawet blokują przekaz. Blokada komunikacji to najczęściej skutek nieznajomości adekwatnego sytuacyjnie słownictwa. Wynika stąd konieczność konsekwentnego prowadzenia badań w zakresie doboru treści leksykalnych odpowiednich do poszczególnych poziomów biegłości językowej oraz skutecznych metod wprowadzania i utrwalania nowego słownictwa. W artykule scharakteryzowano leksykę rosyjskiego subjęzyka biznesu, omówiono najczęstsze techniki wprowadzania, powtarzania i utrwalania leksyki ekonomicznej na poziomie studiów filologicznych.

Słowa kluczowe: nauczanie języków specjalistycznych; język rosyjski w biznesie; komunikacja zawodowa; nauczanie słownictwa.

\section{THE LEXICAL COMPONENT IN TEACHING RUSSIAN BUSINESS COMMUNICATION}

\section{Summary}

The paper focuses on the importance of the lexical component in teaching Russian business communication. It was underlined that the topic is an integral element of business communication, which defines the content of the message and influences mainly the choice of lexis. The importance of lexis as a component of teaching a foreign language changes depending on the aims of teaching. The paper discusses the situation when the primary aim of teaching is the ability of effective communication, the development of business communication competence, in which the knowledge of vocabulary plays a pivotal role. It was proved that the ability of conveying specialist information depends the most on the level of vocabulary knowledge. Limited vocabulary range hinders or even blocks communication the most. Communication block most often results from a lack of knowledge of appropriate situational vocabulary. Consequently, there is a need for continuous research into the choice of lexical content corresponding to different levels of language proficiency as well as into the effective methods of introducing and consolidating new vocabulary. The paper provides a description of the lexis of Business Russian sub-language and discusses the most frequent techniques of introducing, revising and consolidating economic lexis at the level of philological studies.

Key words: teaching specialist languages; Business Russian; business communication; teaching vocabulary. 